\title{
URGENSI MANAJEMEN KELAS UNTUK MENCAPAI TUJUAN PEMBELAJARAN
}

\author{
Yeni Asmara1, Dina Sri Nindianti² \\ 1Pendidikan Sejarah STKIP PGRI Lubuklinggau \\ 2Pendidikan Sejarah Universitas PGRI Palembang \\ Alamat korespondensi: yeni.stkip@gmail.com
}

Diterima: 6 Desember 2018; Direvisi: 20 Januari 2019; Disetujui: 22 Januari 2019

\begin{abstract}
Class management is a benchmark in the achievement of learning objectives effectively and efficiently in the education process, the achievement of educational goals in the broadest sense is if the class management has been properly implemented by class management in the school itself. Class management is an effort to manage students in the classroom that is done to create and maintain the atmosphere or class conditions that support the teaching program by creating a pleasant atmosphere and maintaining the motivation of students to always be involved, participate in the education process at school. Thus the urgency of class management in achieving learning objectives are (1) managerial activities that include the creation and maintenance of conditions can support the optimal implementation of learning so that it is effective and efficient in supporting the achievement of learning objectives. (2) The role of the teacher in class management requires the organization of classes, seating arrangements, arrangement of learning tools, maintenance of the beauty of the classroom, maintenance of class hygiene, and others. (3) Raising the pattern of teacher behavior in classroom management as an effort to improve the quality of education includes the quality of learning based on the abilities of teachers and the condition of students, the ability of teacher to master the curriculum and the ability of teacher to choose learning methods.
\end{abstract}

Keywords: Class management; learning objectives

\begin{abstract}
Abstrak
Manajemen kelas merupakan tolak ukur untuk mencapai apa yang menjadi tujuan pembelajaran secara efektif dan efisien pada proses pendidikan, pada umumnya tujuan pendidikan dikatakan telah tercapai apabila telah terlaksananya secara baik manajemen kelas dalam sekolah itu sendiri. Manajemen kelas diartikan sebagai suatu upaya yang dilakukan oleh guru sebagai manajer kelas dalam mengelola siswa yang berada di dalam kelas yang dilakukanuntuk merancang atau mendesain sehingga mampu menciptakan dan sekaligus dapat mempertahankan suasana yang menyenangkan, menimbulkan motivasi siswa untuk selalu ikut aktif terlibat pada saat proses pembelajaran berlangsung di lingkungan kelas sehingga suasana kondusif seperti itu akan dapat membantu dalam menunjang keberhasilan program pengajaran yang telah direncanakan sebelumnya. Penulisan artikel yang bersifat hasil pemikiran penulis, maka metode penulisan yang digunakan adalah dengan menggunakan metode kepustakaan atau literature yaitu dengan menggali informasi dari artikel atau buku teks yang relevan dengan masalah yang dibahas. Dengan demikian urgensi dari manajemen kelas untuk mencapai tujuan pembelajaran yang telah direncanakan yaitu (1) Kegiatan manajerial yang di dalamnya mengupayakan agar dapat melakukan sebuah kegiatan yang mampu menciptakan dan memelihara kondisi pembelajaran yang kondusif sehingga tercapainya tujuan pembelajaran yang telah ditetapkan sebelumnya dapat tercapai secara efektif dan efisien. (2) Implementasi manajemen kelas yang meliputi kegiatan dalam mengorganisasikan kelas, melakukan pemiliharaan keindahan dan kebersihan ruangan belajar, pengaturan tempat duduk siswa, pengaturan alat-alat pelajaran yang kesemua itu diperlukan peran guru yang besar dalam manajemen kelas tersebut. (3) Dalam pengelolaan kelas diharapkan dapat membangkitkan pola tingkah laku guru dalam meningkatkan mutu pendidikan yang meliputi kualitas pembelajaran yang disesuaikan dengan kemampuan guru dan kondisi siswa, guru diharapkan juga mempunyai penguasaan yang berkaitan dengan kurikulum dan pemilihan serta penggunaan metode pembelajaran yang tepat dan sesuai dengan peserta didik.
\end{abstract}

Kata Kunci: Manajemen kelas; tujuan pembelajaran 


\section{A. Pendahuluan}

Dalam kehidupan lembaga dan organisasi pelaksanaan manajerial merupakan tolak ukur ketika melihat kualitas dari sebuah lembaga atau organisasi dengan melihat seberapa besar hasil pencapaian dari tujuan yang telah ditetapkan secara efektif dan efisien. kegiatan manajerial memiliki arti penting dalam menentukan keberhasilan suatu lembaga. Seperti yang dijelaskan oleh Abdurrahman (2004:17) mendefinisikan "manajemen merupakan suatu proses kegiatan yang diawali dengan kegiatan perencanaan, pengorganisasian, pengkoordinasian, sampai pada kegiatan pengontrolan sumber daya sebagai upaya untuk mencapai sebuah sasaran secara efektif apabila tujuan tersebut dapat dicapai sesuai dengan yang direncanakan dan dikatakan efesien tujuan dapat dicapai sesuai dengan perencanaan, sementara efisien mengandung arti bahwa tugas telah dilaksanakan secara benar, terorganisir, dan sesuai dengan jadwal".

Berdasarkan pendapat di atas apabila manajemen dihubungkan dalam dunia pendidikan, maka manajemen yang akan diwujudkan dalam bentuk administrasi adalah sarana yang digunakan oleh baik individu atau sekelompok orang yang tergabung dalam wadah organisasi atau lembaga pendidikan sebagai suatu upaya untuk mencapai tujan pendidikan baik secara umum maupun secara khusus seperti tercapainya tujuan pembelajaran seefektif dan seefisien mungkin. Tentunya untuk mencapai semua tujuan tersebut maka dibutuhkan peran guru dalam mengimplementasikan dan mengaplikasikan kegiatan manajemen dalam lingkup pendidikan terutama pengaplikasian manajemen kelas oleh guru agar apa yang menjadi tujuan pembelajaran sebelumnya dapat tercapai sesuai dengan yang diharapkan dengan seefektif dan seefisien mungkin dalam pengimplementasiaannya yang telah ditetapkan sebelumnya dapat tercapai secara efektif dan efisien.

Dilihat dari ruang lingkup kerjanya manajemen kelas merupakan inti atau pusat yang menentukan keberhasilan manajemen yang lainnya.Seperti yang dijelaskan oleh Arikunto (2010:6) bahwa "manajemen kelas sebagai suatu kesatuan terkecil dalam usaha pendidikan yang justru merupakan dapur inti dari seluruh jenis manajemen pendidikan.Dengan demikian manajemen kelas merupakan factor mendasar atau factor yang paling urgen untuk menentukan tercapai tidaknya tujuan pendidikan nasional secara umum maupun tujuan pembelajaran secara khususnya sehingga membutuhkan pemahaman dan kesadaran pada guru untuk meningkatkan kualitas perannya sebagai manajer kelas untuk mengaplikasikan manajemen kelas tersebut. Menurut Padmono (2011:10) menyebutkan bahwa" manajemen kelas menunjukkan sebagai suatu kegiatan yang dilakukan oleh guru sebagai usaha dalam membantu mendesain suasana pembelajaran yang menyenangkan atau sebagai upaya guru dalam menciptakan kondisi belajar yang optimal sehingga membantu menimbulkan dan meningkatkan minat dan motivasi belajar siswa". Pengertian lain menjelaskan bahawa manajemen kelas merupakan sebuah proses yang menyeleksi suatu tindakan yang dilakukan guru karena terkait dengan pelaksanaan fungsinya untuk bertanggung jawab atas kelas dan alat- 
alat belajar yang digunakan secara baik dan benar sesuai dengan tujuan, kurikulum, dan karakter siswa yang dihadapi guru saat di kelas.

Manajemen kelas juga dapat diartikan sebagai suatu kegiatan sistematis yang menunjukkan pola tingkah laku guru dalam merancang, menciptakan dan memelihara kondisi kelas yang kondusif sehingga memungkinkan bagi peserta didik untuk mencapai apa yang menjadi tujuan pembelajaran secara efesien dan diharapkan kegiatan tersebut memberikankemungkinan bagi siswa untuk melaksanakanpembelajaran sesuai dengan yang diharapkan.

Dari penjelasan tersebut menjelaskan bahwa manajemen kelas yang diwujudkan dalam pengelolaan kelas oleh guru sebagai suatu kegiatan sistematis sebagai upaya dalam membantu mewujudkan suasana pembelajaran yang optimal sehingga tujuan pembelajaran yang telah direncanakan sebelumnya dapat dicapai secara berdaya guna dan berhasil guna oleh siswa sebagai subjek pembelajaran. Dengan demikian diharapkan guru perlu memiliki pengetahuan dan pandangan yang luas tentang manajemen kelas yang dalam artikel ini akan dibahas mengenai beberapa hal penting yang berkaitan dengan manajemen kelas yaitu; 1. konsep manajemen kelas, 2. tujuan manajemen kelas, 3. Implementasi manajemen kelas, dan 4) urgensi manajemen kelas.

\section{B. Metode Penelitian}

Metode penelitian merupakan cara yang ditempuh peneliti untuk menganalis data, gejala, penomena ataupun fakta-fakta mengenai apa yang akan diteliti (Hadari, 2003:31). Artikel ini merupakan hasil pemikiran dari penulis oleh karena itu teknik penulisan menggunakan teknik literature dengan menggali beberapa informasi baik dari artikel maupun buku teks yang relevan dengan permasalahan yang dibahas.

\section{Pembahasan}

\section{Konsep Manajemen Kelas}

Manajemen kelas seperti yang dijelaskan oleh Djamarah (2006:51) yaitu serangkaian kegiatan sistematis sebagai suatu upaya dalam mendayagunakan potensi kelas yang ada oleh guru dengan seoptimal mungkin sehingga dapat mendukung terjadinya proses interaksi edukatif antara peserta didik dengan tenaga pengajar dalam mencapai tujuan pembelajaran yang telah ditetapkan sebelumnya. Dengan pengertian lain dapat diartikan bahwa manajemen kelas menunjukkan sebagai bentuk pola tingkah laku yang kompleks dari tenaga pengajar dalam hal ini guru sebagai upaya mewujudkan proses pengajaran dan pembelajaran dapat berjalan sesuai dengan yang direncanakan secara efektif dan efisien.

Manajemen kelas sebagai suatu langkah atau strategi yang dapat dilakukan guru untuk dapat membuat siswa aktif dalam melaksanakan aktivitas pada saat proses pembelajaran berlangsung di kelas serta adanya upaya guru dalam mengurangi pola prilakulaku yang kontraproduktif pada saat proses pembelajaran, sehingga diharapkan kegiatan guru dan siswa dalam pelaksanaan proses pembelajaran yang berlangsung di kelas dapat berjalan lancer dan efektif apabila dilihat dari segi waktunya.

Nawawi (2009:115) berpendapat bahwa manajemen kelas adalah usaha dari pihak guru untuk menatakehidupan kelas dimulai dari perencanaan kurikulumnya, penataanprosedur dan sumber belajarnya, pengaturan lingkungannya untukmemaksimumkan efisiensi, memantau kemajuan siswa, 
danmengantisipasi masalah-masalah yang mungkin timbul.Sementara itu Arikunto (2005:26) menjelaskan bahwa manajemen kelas adalah suatu usaha yang dilakukan oleh penanggung-jawab kegiatan belajar-mengajar atau suatu kegiatan denga tujuan membantu peserta didik dalam mencapai kondisi pembelajaran yang optimal, dengan maksud agar program pembelajaran yang telah direncanakan sebelumnya dapat terlaksana sesuai dengan yang diharapkan.

Adapun komponen-komponen dalam manajemen kelas dapat diklasifikasikan ke dalam beberapa bagian yang pertama komponen pengelolaan kelas yang berhubungan dengan siswa dan yang kedua penglolaan kelas non siswa seperti yang berkaitan dengan alat peraga, ruangan dan lingkungan kelas. Seperti yang telah dijelaskan sebelumnya bahwa manajemen kelas menunjukkan sebuah prilaku guru yang kompleks dengan tujuan untuk menjaga dan memelihara suasana kelas yang kondusif sehingga pembelajaran dapat berjalan dengan optimal serta mampu mengembangkan potensi siswa selama mengalami proses pembelajaran. Sementara itu pengertian lain mengenai manajemen kelas yaitu suatu upaya yang dilakukan guru dengan penuh tanggungjawab dalam pelaksanaan kegiatan pembelajaran dengan cara menciptakan suatu kondisi yang optimal sehingga proses pembelajaran dapat berlangsung sesuai dengan yang direncanakan sebelumnya dan pada akhirnya dapat mencapai tujuan pembelajaran yang telah dirumuskan.

Disamping itu ada beberapa tahapan kegiatan dalam pengelolaan manajemen siswa yang meliputi tahap penyelenggaraan, pengurusan, dan ketatalaksanaan dalam menyelenggarakan kelas. Dari penjelasan tersebut maka dapat dikatakan bahwa kegiatan manajerial merupakan kegiatan yang di dalamnya terdapat suatu upaya untuk menciptkan dan memelihara kondisi pembelajaran yang kondusif. Dengan demikian pemeliharaan kondisi kelas seoptimal mungkin dapat mendukung terselenggaranya proses pembelajaran di kelas secara efektif dan efisien sebagai suatu bentuk perwujudan dalam mencapai tujuan pembelajaran. (Padmono, 2011: 12).

Kegiatan tersebut tentunya memilik itujuan agar pelaksanaan manajemen kelas yang dilakukan guru dapat membantu memaksimalkan proses pembelajaran di kelas dalam rangka mencapai tujuan pembelajaran yang telah direncanakan sebelumnya secara efektif dan efisien. Dari beberapa pendapat di atas dapat diambil suatu pengertian bahwa manajemen kelas menunjukkan pada suatu upaya yang dilakukan guru dalam menciptakan dan mempertahankan suasana kelas yang kodusif dengan melakukan pengorganisasian kelas seoptimal mungkin untuk menunjang program pada saat di kelas maka dapat disimpulkan bahwa manajemen kelas merupakan upaya mengelola siswa di dalam kelas yang dilakukan untuk menciptakan dan mempertahankan suasana atau kondisi kelas yang menyenangkan sehingga dapat menimbulkan, membangkitkan serta memelihara atau mempertahankan motivasi belajar siswa agar dapat senantiasa untuk melibatkan diri secara aktif pada saat kegiatan belajar mengajar berlangsung di sekolah.

\section{Tujuan Manajemen Kelas}

Tujuan Manajemen Kelas pada hakikatnya telah terkandung dalam tujuan pendidikan, baik secara umum maupun khusus.Secara umum tujuan 
manajemen kelas adalah penyediaan fasilitas yang membantu siswa agar dapat belajar dan bekerja serta mampu menciptakan suasana sosial yang dapat memberikan kepuasaan, kedisipilinan, mampu mengembangkan kognitif, afektif, dan inspirasi siswa. Kemudian dijelaskan juga tujuan dari pelaksa Sudirman (2007:313) menjelaskan bahwa manajemen kelas bertujuan sebagai berikut: a. Mengupayakan pengajaran agar dapat dilakukan secara maksimal, sehingga dapat mencapai tujuan pembelajaran secara efektif dan efisien.b. Sebagai upaya memberi kemudahan bagi guru dalam melihat, mengamati setiap kemajuan atau perkembangan yang telah dicapai oleh siswa setelah mengalami proses pembelajaran, c. Memberi kemudahan bagi guru dalam mengetahui dan memberikan solusi atas permasalahan yang bersifat urgen untuk dapat didiskusikan di kelas sebagai upaya melakukan perbaikan pengajaran di masa yang akan datang.

Dari pendapat di atas menjelaskan bahwa manajemen kelas mengandung arti sebagai upaya yang dilakukan guru dalam menciptakan kondisi pembelajaran yang kondusif, menyenangkan pada siswa saat berada di kelas sehingga menjadi suatu lingkungan pembelajaran yang memungkinkan siswa dapat mengekplorasi potensi yang dimiliki sesuai dengan bakat dan minat yang dimiliki. Kemudian,dengan manajemen kelas diharapkan hasil yang diperoleh sesuai dengan tujuan yanghendak dicapai. Dengan demikian tujuan khusus dari pelaksanaan manajemen kelas dibagi menjadi dua aspek yaitu dilihat dari aspek siswa dan aspek guru.

Tujuan manajemen kelas dilihat dari aspek siswa sebagai berikut: Membantu siswa dalam memotivasi untuk mengembangkan bertanggungjawab terhadap apa yang dilakukannya sehingga diharapkan dapat membantu mengontrol diri sendiri.b. Dengan adanya manajemen kelas yang dilakukan guru diharapkan dapat meberikan bimbingan kepada siswa agar dapat berprilaku sesuai dengan peraturan yang berlaku di sekolah atau di kelas, sehingga siswa dapat memahami ketika guru memberikan teguran terkait dengan pelaksanaan disiplin tata tertibbaik di sekolah maupun di kelas akan dianggap sebagai suatu peringatan untuk tidak dapat mengulangi prilaku yang salah tersebut dengan penuh tanggung jawab, c. Membangkitkan siswa untuk dapat meningkatkan prilaku tanggung jawab atas tugas-tugas atau kegiatan yang diberikan oleh guru. (Djamarah, 2006:143).

Berdasarkan pendapat di atas dapat disimpulkan bahwa tujuan dari pada manajemen kelas adalah mengupayakan agar peserta didik pada saat mengikuti proses pembelajaran di kelas dapat melakukan aktifitas belajar serta mengerjakan tugas atau kegiatan laiinya sesuai dengan peraturan yang berlaku sehingga menciptkan suasana tertib., selanjutnya dengan adanya manajemen kelas dapat mengembangkan dan membangkitkan sikap siswa untuk bertanggung jawab atas segala prilaku yang ditunjukkan oleh siswa ketika proses pembelajaran berlangsung di kelas sehingga apa yang menjadi tujuan pembelajaran dapat tercapai secara efektif dan efisien.

Kemudian Djamarah (2006:143) kembali memberikan rincian tentang tujuan manajemen kelas bagi guru yaitu: sebagai upaya pengembangan dan pemahaman bagi guru pada saat penyajian pelajaran mulai dari kegiatan pendahuluan sampai dengan penutup dapat berjalan secara efektif dan efisien. b. Mengupayakan guru untuk 
menyadari apa yang akan dilakukannya di kelas harus sesuai dengan kebutuhan siswa serta guru diharapkan memiliki kemampuan dalam memberikan arahan atau bimbingan secara jelas kepada siswa mengenai kesulitan atau masalah yang dihadapi c. Sebagai upaya guru dalam mempelajari atau mengetahui bagaimana merespon tingkah laku siswa yang dianggap menyimpang dari peraturan yang berlaku pada saat proses pembelajaran secara efektif..d. Dengan adanya manajemen kelas diharapkan guru dapat memilih dan menentukan pelaksanaan strategi remedial yang menyeluruh untuk dapat digunakan dalam menghubungkan masalah danprilaku siswa yang ditunjukkan pada saat mengikuti proses pembelajaran di dalam kelas. Dari uraian di atas dapat disimpulkan manajemen kelas mempunyai tujuan bagi guru diantaranya adalah membantu guru dalam mengembangkan dan menyajikan pelajaran secara baik dan tepat, untuk itu setiap guru dituntut untuk mampu menguasaikelas dengan menggunakan berbagai macam pendekatan, mampu menyesuaikan permasalahan yang ada, sehingga tercipta suasana yangkondusif, efektif dan efisien.

\section{Implementasi Manajemen Kelas}

Dalam upaya meningkatkan mutu dan kualitas pendidikan di sekolah diperlukan kemampuan guru dalam mengelola dan melaksanakan manajemen kelas. Sekolah ataupun kelas perluberkembang maju daritahun ke tahun.Karena itu, hubungan baik gurudengan murid perlu diciptakan agar terjalin iklim dan suasana pembelajaranyang kondusif serta menyenangkan. Demikian halnya penataan penampilan fisik dan kelas perlu dibina agar kelas menjadi lingkungan pendidikan yangdapat menimbulkan

sekaligus mengembangkan jiwa berkreasi, disiplin, dan semangatbelajar peserta didik, atas dasar inilah maka diperlukan suatu upaya guru untuk mengimplementasikan manajemen kelas.

Untuk mengimplementasikan manajemen kelas secara efektif dan efisien, guru perlu memiliki pengetahuan mengelola pembelajaran dalamkelas,yang dimulai dari tahap awal seperti kegiatan merencanakan, memiliki pengetahuan luas tentang bagaimana melakukan pengorganisasian kelas yang baik serta diperlukannya sikap kewibawaan guru yang perlu ditingkatkan sehingga memunculkan jiwa kepedulian, semangat mengajar, disiplin mengajar, keteladanan danhubungan manusiawi dengan siswa sebagai moral yang bermartabat dalam rangka membantu mewujudkan suasana pembelajaran di sekolah yang konduksif.Lebih lanjut. Disamping itu juga dalam pengimplementasian manajemen kelas ini guru juga dituntut untuk melakukanfungsinya sebagai manajer atau guru dalam meningkatkan proses pembelajaran, seperti dengan melaksanakan kegiatan pembinaan pada siswa, memberikan saran-saran positif , tukar pikiran atau sumbang saran guru pada siswa sebagai upaya untuk membangkitkan motivasi dan semangat belajar yang pada akhirnya mengupayakan untuk mencapai tujuan pembelajaran itu sendiri.

Mulyasa (2012:57:58) menjelaskan dalam rangka mengimplementasikanmanajemen kelas secara efektif dan efisien ada beberapa upaya seperti guru mengupayakan dirinya harus dapat menjadi manajer kelas yang memiliki jiwa inovasi atau mungkin discovery sehingga memungkinkan adanya suasana baru 
yang dirasakan oleh siswa dalam lingkungan pembelajaran sehingga manajemen kelas yang dilaksanakan dapat dirasakan kualitasnya. Pentingnya kreativitas

dalam mengimplementasikan manajemen kelas dikarenakan guru merupakan figure yang diakui oleh perundang-undang memiliki sejumlah kompetensi yang dimiliki sehingga dapat menjadi teladan dan panutan langsung bagi peserta didik dikelas. Olehkarena itu, guru perlu siap dengan segala kewajiban, baik manajemenmaupun persiapan isi materi pengajaran. Guru juga harus mengorganisasikan kelasnya dengan baik. Jadwal pelajaran, pembagianpeserta didik, kebersihan, keindahan dan ketertiban kelas, pengaturan tempatduduk peserta didik, penempatan alat-alat dan lain-lain harus dilakukandengan sebaik-baiknya.

Pendapat di atas menjelaskan ketika guru mampu mengimplementasikan manajemen kelas secara efektif dan efisien , maka akan membantu terciptanya suasana kelas yang menyenangkan dan penuhdisiplin, hal ini sangat diperlukan sebagai upaya untuk mendorong semangat belajar pesertadidik, dengan demikian kreativitas dan daya cipta guru untuk mengemplementasikanmanajemen kelas perlu terus menerus di dorong dan dikembangkan. Guru dalam mengimplementasikanmanajemen kelas harus dengan baik. Sebelum pembelajaran di mulai guru harus siap segalanya dalam pembelajaran. Termasuk dalam hal ini adalah prilaku guru yang juga dapat mempengaruhi dalam pembelajaran dan siswanya.

Dalam mengimplementasikan manajemen kelas, guru harus memperhatikan langkah-langkah pengelolaan dalam proses belajar pembelajaran. Seperti yang dijelaskan secara rinci oleh Yamin (2009:18) sebagai berikut: Perencanaan, meliputi: a. pada kegiatan ini guru melakukan pertimbangan tentang apa yang akan dilakukan, dan kapan dan cara yang akan ditempuh untuk mencapai tujuan pembelajaran.b. Kegiatan berikutnya adalah membatasi sasaran yang akan denga dikuti penetapan untuk melaksanakan kerja agar hasil belajar yang telah dirumuskan dapat tercapai secara maksimal dengan melalui proses penentuan target agar dapat berjalan secara efektif dan efisien. c. Langkah berikutnya adalah pengembangan alternative pemecahan masalah $d$. Mengumpulkan dan menganalisis informasi e. Kemudian langkah berikutnya adalah guru dapat melaksanakan dan mengkomunikasikan segala rencana yang merupakan hasil keputusan pada tahap sebelumnya. Pengorganisasian meliputi: a. Menyediakan fasilitas, perlengkapan, dan tenaga kerja yang diperlukanuntuk penyusunan kerangka yang efisien dalam melaksanakanrencana-rencana melalui suat prosespenetapan kerja yang diperlukanuntuk menyelesaikannya.b. Memgelompokkan komponen kerja kedalam struktur organisasi secara teratur.c. Membentuk struktur wewenang dan mekanisme koordinasi d. Merumuskan dan menetapkanmetode dan prosedure. Memilih, mengadakan pelatihan daripendidkan tenaga kerja sertamencari sumber-sumber lain yang diperlukan.3. Pengarahan meliputi :a. Pada tahap ini guru dapat melakukan penyusunan mengenai kerangka waktu dan biaya secara terperinci.b. Guru dapat menjadi prakarsa dan menunjukkan jiwa kepemimpinan ketika akan melaksanakan sebuah rencana dan melakukan pengambilan keputusan.c. Guru dapat mengeluarkan intruksi-intruksi yang spesifik.d. Membimbing, memotivasi, dan melakukan sepervisi. 4. Pengawasan 
meliputi : a. mengevaluasi pelaksanaan kegiatan di bandaingkan dengan rencana.b. Melaporkan penyimpanganuntuk tindakan korelasi dan merumuskantindakan korelasi, menyusun standar-setandar dan saransaran.c. Guru melakukan penilai mengenai apa yang telah dikerjakan dengan menghubungkan pada tindakan yang dianggap menyimpang.

Dari pendapat di atas maka dapat diambil pengertian bahwasanyan pengelolaan dalam pembelajaran tanpa adanya rencana, pengorganisasian, pengarahan,pengawasan.maka

pelaksanaan pembelajaran tidak akan tersusun dengan baik dan tertib. Dengan adanya semua itu diharapkan pelaksanaan pembelajaran akan terlaksana dengan mudah. Ada hal yang juga harus diperhatikan oleh guru disamping pelaksanaan manajemen kelas yaitu prosedur manajemen kelas seperti yang dijelaskan oleh Mulyasa (2012:32) sebagai berikut: Upaya untuk menciptakan danmempertahankan suasana kelas agar membentuk dan menjadikan siswa memiliki motivasi yang tinggi, guru dapat menerapkan manajemen kelas preventif dan kuratif yang kedua hal tersebut memiliki prosedur manajemen yang berbeda. Manajemen kelas preventif dilakukan apabila guru memiliki inisiatif sendiri dalam mengupayakan menciptakan suatu kondisi interaksi yang menyenangkan, menarik siswa sehingga menimbulkan suasana pembelajaran yang kondusif yang dirasakan nyaman dan luar biasa oleh siswa, yang pada akhirnya proses pembelajaran seperti itu dapat membawa keuntungan terutama dalam pencapaian tujuan pembelajaran. Sementara itu manajemen kelas kuratif adalah yang dilaksanakan karena terjadi penyimpangan pada tingkah laku siswa, sehinggamengganggu jalannya proses pembelajaran.
Untuk melaksanakan kedua manajemen kelas tersebut guru sebagai manajer dapat memperhatikan langkahlangkah seperti yang dijelaskan oleh Mulyasa (2012:33) sebagai berikut: Prosedur Manajemen Kelas yang bersifat Preventif meliputi :1) Diperlukannya upaya untuk meningkatan kesadaran dari pendidik sebagai seorang guru merupakan tahap yang paling mendasar dalam pelaksanaan strategi manajemen kelas. Artinya pada pelaksanaan manajemen kelas bersifat preventif factor yang paling utama adalah bagaimana meningkatkan kesadaran diri pendidik sebagai guru karena pada dasarnya guru harus memiliki keyakinan dan penuh tanggung jawabdalam melaksanakan proses pedidikan pada umumnya dan pembelajaran khususnya. Dengan demikian bagaimanapun karakteristik atau corak dari bentuk pelayanan pendidikan yang diberikan kepada siswa, tentu semuanya itu merupakan tanggungjawab yang harus dipahami oleh guru. 2) Peningkatan Kesadaran Siswa, kesadaran akan hak dan kewajibannya dalam prosespendidikan ini baru akan diperoleh secara menyeluruh danseimbang jika siswa itu menyadari akan kebutuhannya dalamproses pendidikan yang penyadaran itu dibantu oleh peran serta guru, sehingga siswa yang memiliki kesadaran yang tinggi mampu berperan sebagai anggota masyarakat sekolah serta dapat menimbulkan suasana yang kondusif untuk melakukan proses pembelajaran.3) Penampilan Sikap Guru yang diwujudkan dalam interaksinyadengan siswa yang disajikan dengan sikap tulus dan hangat.Dengan sikap yang tulus dan hangat dari guru, diharapkanproses interaksi dan komunikasinya berjalan wajar, sehinggamengarah kepada suatu 
penciptaan suasana yang mendukunguntuk kegiatan pendidikan.4) Pengenalan Terhadap Tingkah Laku SiswaTingkah laku siswa yang harus dikenal adalah tingkah lakubaik yang mendukung maupun yang dapat mencemarkansuasana yang diperlukan untuk terjadinya proses pendidikan. Identifikasi akan variasi tingkah laku siswa itudiperlukan bagi guru untuk menetapkan polaatau pendekatan yang akan dilakukan dalam manajemen kelas ketika menghadapi situasi kelas tertentu.5) melakukan pemilihan dan penentuan alternative tindakan manajemen kelas yang sesuai dengan situasi yang dihadapinya, sehingga langkah ini sangat diperlukan sekali upaya dari pendidik untuk dapat memahami berbagai pendekatan yang nantinya dapat digunakan dalam mengiplmentasikan manajemen kelas.6) Pembuatan Kontrak SosialKontrak sosial pada hakekatnya berupa norma yangdituangkan dalam bentukperaturan atau tatatertib kelas baiktetulis maupun tidak tertulis, yang berfungsi sebagai standartingkah laku bagi siswa sebagai individu maupun sebagaikelompok.

Prosedur Manajemen Kelas yang bersifat Kuratif meliputi :1) Identifikasi Masalah, guru melakukan identifikasi dengan jalan guru dapat berusaha untuk memahami dan melakukan penyelidikan terhadap penyimpangan pada masalah tingkah laku siswa yang dapat mengganggu kelancaran proses pembelajaran di dalam kelas 2) Analisis Masalah dengan berusahamengetahui latar belakang serta sebab-akibat timbulnya permasalahan tingkah laku siswa yang menyimpang tersebut.3) Penetapan Alternatif Pemecahan,untuk dapat memperoleh alternatif-alternatif pemecahantersebut, hendaknya guru dapat mengetahui berbagai pendekatan pembelajaran yang dapat digunakan dalam manajemen kelas dapat menempuh cara-cara dalam mengatasi setiap masalah yang dihadapi siswa sesuai dengan pendekatan yang sesuai dengan masing-masing siswa, 4) Monitoring, kegiatan ini penting dilakukan,sebagai akibat dari perlakuan guru yang dapat mengenai sasaran dalam hal ini terjadi perubahan yang mengarah pada suatu tindakan atau prilaku postif dari siswa atau sebaliknyaapa yang telah dilakukan oleh guru dalam manajemen kelas tidak memberikan dampak perubahan yang berarti bagi siswa sehingga prilaku yang menyimpang masih ditunjukkan siswa pada saat di kelas atau di sekolah. 5) Memanfaatkan Umpan Balik (FeedBack), hasil monitoring tersebut, hendaknya dimanfaatkan secarakonstruktif, yaitu dengan caramempergunakannya untuk :a) dapat melakukan perbaikan sebagai upaya dalam pengambilan alternative pemecahan masalah yang pernahditetapkan ketika guru menghadapi permasalahan yang sama padasituasi yang sama.b) Untuk melaksanakan kegiatan manajemen kelas pada periode berikutnya didasarkan pada hasil monitoring dari kegiatan manajemen kelas yang sudah dilakukan sebelumnya, sehingga apa yang akan diharapkan dapat terlaksana secara efektif dan efisien.

\section{Urgensi Manajemen Kelas}

Sebagai usaha dalam meningkatkan mutu pendidikan nasional yang sesuai dengan cita-cita bangsa Indonesia , dalam mewujudkan kesejahteraan umum dan mencerdaskan kehidupan bangsa, meningkatkan ketakwaan kepada Tuhan Yang Maha Esa, kecerdasan, dan ketrampilan.makadiperlukan suatu tugas dan peran guru dalam proses pembelajaran yang tugas guru bukan hanya kegiatannya mendidik, mengajar 
dan melatih tetapi guru juga harus berpikir bagaimana guru dapat membaca situasi kelas dan kondisi siswanya agar mudah dalam menerima transfer pelajaran sehingga apa yang menjadi tujuan pembelajaran dapat tercapai. Hal ini penting untuk dipahami dikarenakan pendidik dalam hal ini guru dianggap sebagai unsur utama atau dapat dikatakan sebagai figur sentral dalam tercapainya sebuah keberhasilan pendidikan artinya di tangan gurulah terletak kemungkinan berhasil atau tidaknya pencapaian tujuan belajar mengajar di sekolah.

Untuk meningkatkan kualitas proses belajar dan pembelajaran sehingga diperoleh hasil yang maksimal maka diperlukan peranan yang besar dari guru untuk mencapai hal tersebut salah satunya dengan berupaya untuk menciptakan lingkungan belajar atau kondisi kelas yang menyenangan, aman, dan nyaman bagi siswa sehingga proses kegiatan belajar mengajar dapat lebih efektif dan efisien ketika guru memiliki kemampuan dalam mengelola kelas. Menurut Sanjaya (2008:10) bahwa "kelas" merupakan lingkungan belajar dan bagian dari suatu aspek lingkungan sekolah yang perlu diorganisir sebaik mungkin dengan kata lain guru dapat mengatur kondisi pembelajaran seoptimal mungkin serta melakukan pengawasan atas kegiatanyang direncanakan dalam proses belajar mengajar sehingga mengarah pada ketercapaian tujuan pendidikan". Manajemen kelas yang dihubungkan dengan adanya kegiatan pengelolaan kelas dapat diberikan batasan menurut bagaimana pendekatan pengelolaan yang diselenggarakan sekolah atau lembaga pendidikan tertentu. Menurut Abdurahman (2004: 42), bahwa kelas meliputi berbagai komponen, antara lain: ruangan, siswa, kegiatan pembelajaran, alat dan media pembelajaran (instrumental), serta segala hal yang berhubungan dengan suasana lingkungan belajar (environmental).

Dari pendapat tersebut menjelaskan bahwa guru diharapkan dapat menciptkan lingkungan belajar yang kondusif yaitu yang dapat memberikan tantangan, dorongan dan pengalaman belajar bagi siswa di sekolah sehingga dengan kondisi lingkungan belajar seperti itu siswa merasakan kenyamanan dan kepuasaan dalam memperoleh hasil belajar yang maksimal, oleh karena itu untuk mewujudkan hal tersebut sangat dibutuhkan peranan guru dalam mengimplementaskan manajemen kelas yang dapat diwujudkan dalam bentuk pengelolaan kelas seperti yang telah diuraikan di atas .

Ali (2008:19) menjelaskan “pengelolaan kelas merupakan ditujukan sebagai upaya dan tindakan guru dalam melakukan pembinaan pada siswa, melakukan mobilisasi, serta pemberdayaan kelas secara optimal dengan selektif dan efektif yang diwujudkan dengan menciptakan kondis belajar yang menyenangkan atau suatu kegiatan yang memperlihatkan kemampuan guru dalam menyelesaikan problema yang dihadapi kelas agar proses belajar mengajar dapat berlangsung dengan wajar. Keberhasilan guru dalam melakukan pengelolaan kelas dapat dilihat dari kemampuan guru dalam mengatur dan mengendalikan komponen-komponen pembelajaran yang ada di kelas seperti siswa dan sarana pengaaran sehingga dapat menciptakan kondisi belajar mengajar yang menyenangkan, dengan demikian mempermudah guru dalam upaya pencapaian tujuan pembelajaran. .Disamping itu juga diperlukan upaya guru dalam menjaga hubungan 
interpersonal yang baik dengan siswa, antara siswa dengan siswa lainya, yang kesemua itu merupakan syarat dalam mencapai keberhasilan pengelolaan kelas.

Proses belajar mengajar dapat berlangsung dengan efektif jika diiringi dengan pengelolaan kelas yang efektif juga dan hal tersebut merupakan syarat mutlak dalam menciptakan suasana kelas yang tenang, dan aman sekaligus dapat membangkitkan minat dan perhatian serta motivasi siswa dalam belajar. Faktor utama dalam menentukan derajat keaktifan belajar siswa adalah minat. Oleh karena itu guru dapat mengupayakan menciptakan kondisi pembelajaran kondusif, menyenangkan dan mampu mengaktifkan semua ranah siswa temasuk fisik, emosi dan mental yang dapat dilakukan secara langsung sehingga menimbulkan pembelajaran yang bermakna bagi siswa. Artinya siswa tidak hanya sekedar menerima dan menghafal hasil transfer materi dari guru tetapi ada hal yang terpenting yaitu terbentuknya sikap ilmiah pada diri siswa.

Zamroni (2013:93) menjelaskan urgensi manajemen kelas yaitu dapat dilihat dari berbagai aspek dalam pendidikan dan proses belajar mengajar yaitu; (1) Kegiatan manajerial yang mencakup tahap penciptaan dan pemeliharaan kondisi belajar yang maksimal sehingga dapat memungkinkan untu terselenggaranya kegiatan pembelajaran yang efektif dan efisien dalam upaya untuk mempermudah dalam pencapaian tujuan pembelajaran. (2) Dibutuhkan peran guru dalam menerapkan manajemen kelas yang dimulai dari tahap pengorganisasian kelas, pengaturan tempat duduk, pengaturan alat-alat pelajaran, pemeliharaan keindahan dan kebersihan ruangan kelas, dan lain-lain. (3) Pengelolaan kelas sebagai upaya dalam meningkatkan mutu pembelajaran adalah sebagai cerminan dari pola tingkah laku guru di kelas yang dirancang sedemikian rupa sesuai dengan kreatifitas dan inovasi guru dan karakteristik siswa dengan diiringi kemampuan guru yang lain seperti penguasaan kurikulum, kemampuan memilih dan menggunakan sumber dan media pembelajaran yang tepat.

Dari uraian di atas dapat diambil suatu pengertian bahwa urgensi dari manajemen kelas sebagai upaya untuk memperoleh tujuan pembelajaran yang maksimal efektif dan efisien dapat dilakukan guru dengan menciptakan dan memelihara kondisi pembelajaran yang kondusif, menyenangkan sehingga membuat siswa memiliki rasa nyaman dan kepuasaan dalam mengikiuti proses pembelajaran yang diselenggarakan serta diperlukannya peran guru dalam menerapkan manajemen kelas seperti melakukan kegiatan pengorganisasian kelas yang diwujudkan dalam sebuah pola tingkah laku guru untuk melakukan pengelolaan kelas mulai dari pengaturan ruangan, tempat duduk, media, alat dan bahan pelajaran yang akan disajikan sampai pada penentuan alternatif pemecahan masalah yang akan dihadapi siswa saat mengikuti proses pembelajaran di kelas sehingga mutu atau kualitas dari pendidikan yang diharapkan dapat tercapai sesuai dengan yang telah direncanakan sebelumnya.

\section{Kesimpulan}

Dari hasil pembahasan maka dapat disimpulkan bahwa konsep manajemen kelas menunjukkan suatu upaya yang dilakukan guru dalam melakukan pengelolaan siswa dalam proses pembelajaran di kelas dengan melakukan serangkaian kegiatan yang 
sistematis dalam menciptakan dan memelihara lingkungan atau kondisi kelas yang kondusif dan menyenangkan sehingga dapat menunjang program pengajaran yang telah direncanakan sebelumnya serta dapat menimbulkan, meningkatkan serta mempertahankan motivasi belajar siswa sehingga diharapkan siswa dapat selalu aktif dalam melibatkan diri pada saat proses pembelajaran atau dapat berperan aktif pada proses pendidikan di sekolah. Dengan arti lain bahwa manajemen kelas merupakan pola prilaku guru yang kompleks yang ditunjukkan dengan berbagai kegiatan yang dilakukan sebagai suatu upaya agar dapat menciptkan dan memelihara kondisi pembelajaran yang menyenangkan sehingga siswa dapat mengembangkan potensi yang dimiliki secara optimal dan tercapai tujuan pembelajaran secara efektif dan efisien.

Adapun tujuan manajemen kelas agar proses pembelajaran dapat berlangsung dengan optimal dan sesuai dengan perencanaan kegiatan sebelumnya sehingga tujuan umum dan khusu dari pembelajaran dapat dicapai secara efektif dan efisien serta membantu memberikan kemudahan bagi siswa dalam mengekplorasi potensi yang dimiliki sesuai dengan minat dan bakat yang dimiliki. Dengan kata lain manajemen kelas juga bertujuan untuk mengupayakan agar peserta didik pada saat mengikuti proses pembelajaran di kelas dapat melakukan aktifitas belajar serta mengerjakan tugas atau kegiatan laiinya sesuai dengan peraturan yang berlaku sehingga menciptkan suasana tertib dan mampu mengembangkan serta membangkitkan sikap siswa untuk bertanggung jawab atas segala prilaku yang ditunjukkan oleh siswa ketika proses pembelajaran berlangsung di kelas sehingga apa yang menjadi tujuan pembelajaran dapat tercapai secara efektif dan efisien.

Untuk mengimplementasikan manajemen kelas secara efektif danefisien, guru perlu memiliki pengetahuan mengelola pembelajaran dalamkelas,yang dimulai dari tahap awal seperti kegiatan merencanakan, memiliki pengetahuan luas tentang bagaimana melakukan pengorganisasian kelas yang baik serta diperlukannya sikap kewibawaan guru yang perlu ditingkatkan sehingga memunculkan jiwa kepedulian, semangat mengajar, disiplin mengajar, keteladanan dan hubungan manusiawi dengan siswa sebagai moral yang bermartabat dalam rangka membantu mewujudkan suasana pembelajaran di sekolah yang konduksif. Disamping itu juga dalam pengimplementasian manajemen kelas ini guru juga dituntut untuk melakukanfungsinya sebagai manajer atau guru dalam meningkatkan proses pembelajaran, seperti dengan melaksanakan kegiatan pembinaan pada siswa, memberikan saran-saran positif , tukar pikiran atau sumbang saran guru pada siswa sebagai upaya untuk membangkitkan motivasi dan semangat belajar yang pada akhirnya mengupayakan untuk mencapai tujuan pembelajaran itu sendiri.

Adapun Urgensi manajemen kelas dalam mencapai tujuan pembelajaran yaitu (1) Kegiatan manajerial yang meliputi kegiatan dalam upaya untuk menciptakan dan memelihara kondisi kelas yang kondusif dan menyenangkan yang dapat memungkinkan terlaksananya proses pembelajaran seoptimal mungkin sehingga tujuan pembelajaran dapat dicapai secara efektif dan efisien. (2) Peran guru dalam pengimplementasian manajemen kelas dapat meliputi kegiatan seperti pengorganisasian kelas, pengaturan tempat duduk siswa, pengaturan alat 
dan bahan serta media pelajaran, pemeliharaan keindahan dan kebersihan ruangan kelas, , dan lain-lain. (3) Pola tingkah laku guru dalam melakukan pengelolaan kelas sebagai upaya dalam meningkatkan mutu pendidikan secara umum dan kualitas pembelajaran secara khusus dapat diwujudkan diantaranya adanya kemampuan guru dalam memahami dan menguasai kurikulum,serta penguasaan dalam memilih metode dan media pembelajaran yang sesuai dengan tujuan, materi dan karakteristik siswa.

\section{Daftar Referensi}

Abdurrahman., 2004. Pengelolaan Pengajaran. Ujung Pandang : Bintang Selatan.

Ahmadi, Abu,dkk.1991. Psikologi Belajar. Jakarta : Rineka Cipta.

Ali, Muhammad. 2008. Guru dalam Proses Belajar Mengajar. Bandung : Sinar Baru Algensindo.

Arikunto, Suharsimi,dkk. 2010.

Manajemen Pendidikan. Jakarta: Rineka Cipta.

Arikunto, Suharsimi. 2005. Pengelolaan Kelas dan Siswa. Jakarta. Rineka Cipta.

Djamarah, Bahri, Syaiful. 2006. Guru dan Anak Didik dalam Interaksi Edukatif Suatu Pendekatan Teoritis Psikologis. Jakarta: PT. Rineka Cipta.

Mulyasa, E. 2012. Manajemen Berbasis Sekolah Konsep, Strategi, Dan Implementasi. Bandung: PT. Remaja Rosdakarya.

Nawawi, Hadari.2003. Metode Penelitian Bidang Sosial. Gajah Mada Universitas Press.
Padmono, Y. 2011. Manajemen Kelas. Salatiga: Widyasari.

Sanjaya, Wina. 2008. Perencanaan dan Desain Sistem Pembelajaran. Bandung:Kencana.

Sudirman N, dkk. 2007. Ilmu Pendidikan. Bandung : Remadja Karya.

Yamin, Martinis., dkk. 2009. Manajemen Pembelajaran Kelas Strategi Meningkatkan Mutu Pembelajaran. Jakarta : Gaung Persada Press.

Zamroni. 2013. Manajemen Pendidikan Suatu Usaha Meningkatkan Mutu Sekolah. Yogyakarta:Ombak. Penelitian (Suatu Pendekatan Praktek). Jakarta:Rineka Cipta. 